Acknowledgements: AbbVie funded this study and participated in the study design, research, analysis, data collection, interpretation of data, reviewing, and approval of the publication. All authors had access to relevant data and participated in the drafting, review, and approval of this publication. No honoraria or payments were made for authorship. Medical writing assistance was provided by Frances Smith, PhD, of 2 the Nth, which was funded by AbbVie.

Disclosure of Interests: Bernard Combe Speakers bureau: AbbVie, Eli Lilly, Gilead, Janssen, Merck, Novartis, Pfizer, Roche-Chugai, Sanofi, and UCB Pharma, Consultant of: AbbVie, Eli Lilly, Gilead, Janssen, Merck, Novartis, Pfizer, Roche-Chugai, Sanofi, and UCB Pharma, Frank Buttgereit Speakers bureau: AbbVie, Eli Lilly, Pfizer, and Roche, Andrew Ostor Consultant of: AbbVie, Bristol-Myers Squibb, Eli Lilly, Gilead, Janssen, Novartis, Paradigm, Pfizer, Roche, and UCB Pharma., Ricardo Xavier Speakers bureau: AbbVie, Eli Lilly, Janssen, Novartis, Pfizer, Roche, and UCB Pharma, Consultant of: AbbVie, Eli Lilly, Janssen, Novartis, Pfizer, Roche, and UCB Pharma, Alain Saraux Speakers bureau: AbbVie, Bristol-Myers Squibb, Chugai, Eli Lilly, Nordic, Sanofi, and UCB Pharma, Consultant of: AbbVie, Bristol-Myers Squibb, Chugai, Eli Lilly, Nordic, Sanofi, and UCB Pharma, Capucine DARIDON Shareholder of: AbbVie, Employee of: AbbVie, Kirsten Famulla Shareholder of: AbbVie, Employee of: AbbVie, Yanna Song Shareholder of: AbbVie, Employee of: AbbVie, Ivan Lagunes-Galindo Shareholder of: AbbVie, Employee of: AbbVie, Gerd Rüdiger Burmester Speakers bureau: AbbVie, Eli Lilly, Gilead, Janssen, Merck, Pfizer, Roche, and UCB Pharma, Consultant of: AbbVie, Eli Lilly, Gilead, Janssen, Merck, Pfizer, Roche, and UCB Pharma

DOI: 10.1136/annrheumdis-2021-eular.480

\section{POS0655 LONG-TERM SAFETY AND EFFICACY OF UPADACITINIB IN PATIENTS WITH RHEUMATOID ARTHRITIS: 3-YEAR RESULTS FROM THE SELECT- EARLY STUDY}

R. van Vollenhoven ${ }^{1}$, T. Takeuchi' ${ }^{2}$, J. Aelion ${ }^{3}$, N. Chávez ${ }^{4}$, P. Mannucci Walter ${ }^{5}$,

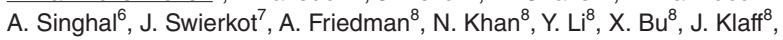
V. Strand ${ }^{9} .{ }^{1}$ Amsterdam UMC, Rheumatology, Amsterdam, Netherlands; ${ }^{2}$ Keio University School of Medicine, Rheumatology, Tokyo, Japan; ${ }^{3}$ Arthritis Clinic PLLC, Rheumatology, Jackson, United States of America; ${ }^{4}$ Instituto Guatemalteco de Seguridad Social, Rheumatology, Ciudad de Guatemala, Guatemala; ${ }^{5}$ Aprillus Asistencia e Investigación, Rheumatology, Buenos Aires, Argentina; 'SouthWest Rheumatology Research, LLC, Rheumatology, Dallas, United States of America; ${ }^{7}$ Wroclaw Medical Hospital, Department and Clinic of Rheumatology and Internal Medicine, Wroclaw, Poland; ${ }^{8}$ AbbVie Inc, Immunology, North Chicago, United States of America; ${ }^{9}$ Stanford University, Division Immunology/Rheumatology, Palo Alto, United States of America

Background: Upadacitinib (UPA), an oral Janus kinase inhibitor, demonstrated significant improvements in signs, symptoms, and structural inhibition as monotherapy (mono) vs methotrexate (MTX) in MTX-naïve patients (pts) with rheumatoid arthritis (RA) through 48 weeks (wks). ${ }^{1}$

Objectives: To report the efficacy and safety of UPA vs MTX mono up to 156 wks in pts with RA from the ongoing long-term extension (LTE) of the SELECTEARLY trial.

Methods: During the 48-wk double-blind study period, pts were randomized to UPA 15 or $30 \mathrm{mg}$ once daily (QD) or MTX (titrated to $20 \mathrm{mg} / \mathrm{wk}$ by Wk 8 ). At Wk 26, pts who did not achieve Clinical Disease Activity Index (CDAl) remission $(\leq 2.8)$ and had $<20 \%$ improvement from baseline in tender or swollen joint count received blinded rescue therapy (addition of MTX for UPA groups and UPA 15 or $30 \mathrm{mg}$ for MTX group). In the LTE, pts received open-label treatment once the last pt reached Wk 48. Efficacy assessments up to Wk 156 were summarized by randomized group and included American College of Rheumatology (ACR) responses, remission and low disease activity (LDA) measures, and change in modified Total Sharp Score (mTSS; up to 96 wks). Treatment-emergent adverse events (AEs) per 100 pt-years (PY) for pts on continuous mono were summarized through 156 wks. Non-responder imputation was used for binary endpoints for missing data and when pts received rescue therapy or prematurely discontinued the study drug. Results: Of 945 pts randomized and treated, 775 entered the LTE on study drug (including 57 rescued pts; MTX, 33; UPA $15 \mathrm{mg}, 17$; UPA $30 \mathrm{mg}, 7$ ). Overall, $161(21 \%)$ pts discontinued during the LTE. At Wk 156, higher proportions of pts randomized to UPA achieved a $20 / 50 / 70 \%$ improvement in ACR response (ACR20/50/70), LDA, and remission vs MTX (Figure 1). Change from baseline in mTSS at Wk 96 favored UPA vs MTX (data not shown). Most AEs were numerically more frequent with UPA $30 \mathrm{mg}$. The overall rate of serious infection was numerically higher with UPA vs MTX (Table 1). Herpes zoster (HZ), neutropenia, non-melanoma skin cancer (NMSC), and creatine phosphokinase (CPK) elevation were more frequent with UPA vs MTX. Two active tuberculosis (TB) events were reported in each UPA arm; 3 adjudicated gastrointestinal (GI) perforation events were observed in the UPA $30 \mathrm{mg}$ arm. Adjudicated major adverse cardiovascular events (MACEs) or venous thromboembolic events (VTEs) were comparable across treatment arms.
Conclusion: UPA monotherapy showed sustained clinically meaningful responses including remission vs MTX through Wk 156 but higher rates of several $A E s$, including $H Z$, neutropenia, and CPK elevations; no new safety risks were observed compared with previous results. ${ }^{1,2}$

\section{REFERENCES:}

[1] van Vollenhoven R, et al. Ann Rheum Dis 2019;78:376-7; 2. Cohen SB, et al. Ann Rheum Dis 2020;annrheumdis-2020-218510.

Table 1. Safety overview

\begin{tabular}{|c|c|c|c|}
\hline E/100 PY $(95 \% \mathrm{Cl})$ & $\begin{array}{c}\text { MTX mono } \\
(\mathrm{n}=314 ; \mathrm{PY}=601.9)\end{array}$ & $\begin{array}{l}\text { UPA } 15 \mathrm{mg} \text { QD mono } \\
(\mathrm{n}=317 ; \mathrm{PY}=703.4)\end{array}$ & $\begin{array}{l}\text { UPA } 30 \mathrm{mg} \text { QD mono } \\
(\mathrm{n}=314 ; \mathrm{PY}=687.6)\end{array}$ \\
\hline Any AE & $\begin{array}{c}240.2 \\
(228.0,252.9)\end{array}$ & $\begin{array}{c}268.0 \\
(256.0,280.4)\end{array}$ & $\begin{array}{c}292.5 \\
(279.8,305.5)\end{array}$ \\
\hline Any serious $A E$ & $10.8(8.3,13.8)$ & $12.2(9.8,15.1)$ & $16.3(13.4,19.6)$ \\
\hline $\begin{array}{l}\text { Any AE leading to discon- } \\
\text { tinuation of study drug }\end{array}$ & $6.5(4.6,8.9)$ & $7.3(5.4,9.5)$ & $7.7(5.8,10.1)$ \\
\hline Any death ${ }^{\mathrm{a}}$ & $0.7(0.2,1.7)$ & $0.9(0.3,1.9)$ & $1.0(0.4,2.1)$ \\
\hline Serious infection & $2.5(1.4,4.1)$ & $3.3(2.1,4.9)$ & $4.4(2.9,6.2)$ \\
\hline $\begin{array}{l}\text { Opportunistic infection } \\
\text { excluding TB and } \mathrm{HZ}\end{array}$ & $0.2(0.0,0.9)$ & $0.1(0.0,0.8)$ & $0.3(0.0,1.1)$ \\
\hline $\mathrm{HZ}$ & $0.8(0.3,1.9)$ & $4.5(3.1,6.4)$ & $4.7(3.2,6.6)$ \\
\hline Active TB & 0 & $0.3(0.0,1.0)$ & $0.3(0.0,1.1)$ \\
\hline NMSC & 0 & $0.4(0.1,1.2)$ & $1.0(0.4,2.1)$ \\
\hline $\begin{array}{l}\text { Malignancy other than } \\
\text { NMSC }\end{array}$ & $1.0(0.4,2.2)$ & $0.6(0.2,1.5)$ & $1.2(0.5,2.3)$ \\
\hline Hepatic disorder & $14.1(11.3,17.5)$ & $12.5(10.0,15.4)$ & $15.0(12.2,18.2)$ \\
\hline Gl perforation ${ }^{b}$ & 0 & 0 & $0.4(0.1,1.3)$ \\
\hline Neutropenia & $2.2(1.2,3.7)$ & $4.5(3.1,6.4)$ & $5.7(4.0,7.8)$ \\
\hline CPK elevation & $1.8(0.9,3.3)$ & $7.7(5.8,10.0)$ & $15.4(12.6,18.6)$ \\
\hline MACE $^{\mathrm{b}}$ & $0.3(0.0,1.2)$ & $0.4(0.1,1.2)$ & $0.6(0.2,1.5)$ \\
\hline VTE $^{b}$ & $0.3(0.0,1.2)$ & $0.4(0.1,1.2)$ & $0.6(0.2,1.5)$ \\
\hline
\end{tabular}

Data were censored at the time of MTX or UPA addition for rescued pts

ancludes treatment-emergent ( $\leq 30$ days after the last dose of study drug) and non-treatment-emergent deaths. ${ }^{\mathrm{b}}$ Adjudicated

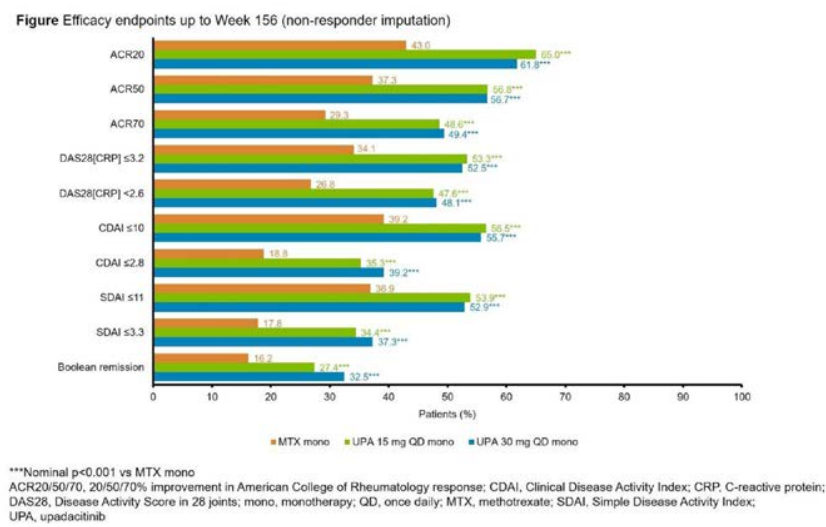

Acknowledgements: AbbVie funded this study; contributed to its design; participated in data collection, analysis, and interpretation of the data; and in the writing, review, and approval of the abstract. No honoraria or payments were made for authorship. Medical writing support was provided by Russell Craddock $\mathrm{PhD}$, of 2 the Nth (Cheshire, UK), and was funded by AbbVie.

Disclosure of Interests: Ronald van Vollenhoven Speakers bureau: AbbVie, AstraZeneca, Biotest, Bristol-Myers Squibb, Galapagos, Gilead, GSK, Janssen, Pfizer, Sanofi, Servier, UCB, and Viela Bio, Consultant of: AbbVie, AstraZeneca Biogen, Biotest, Bristol-Myers Squibb, Galapagos, Gilead, GSK, Janssen, Pfizer Sanofi, Servier, UCB, and Viela Bio, Grant/research support from: Bristol-Myers Squibb, GSK, Eli Lilly, Pfizer, Roche, and UCB, Tsutomu Takeuchi Speakers bureau: AbbVie, AYUMI, Bristol-Myers Squibb, Chugai, Daiichi Sankyo, Dainippon Sumitomo, Eisai, Gilead, Mitsubishi Tanabe, Novartis, Pfizer, and Sanofi, Consultant of: Astellas, Chugai, and Eli Lilly, Grant/research support from: AbbVie, Asahi Kasei, Astellas, Chugai, Daiichi Sankyo, Eisai, Mitsubishi Tanabe, Nippon Kayaku, Shionogi, Takeda, and UCB, Jacob Aelion Grant/research support from: AbbVie, Amgen, AstraZeneca, Bristol-Myers Squibb, Celgene, El Lilly, Galapagos/Gilead, Genentech, GSK, Horizon, Janssen, Mallinckrodt, Nektar, Nichi-Iko, Novartis, Pfizer, Regeneron, Roche, Sanofi, Selecta, and UCB Nilmo Chávez Speakers bureau: AbbVie, Janssen, and Pfizer, Consultant of AbbVie, Janssen, and Pfizer, Grant/research support from: AbbVie, Galapagos Gilead, Pfizer, and Sanofi, Pablo Mannucci Walter Consultant of: AbbVie, Grant/ research support from: AbbVie, Bristol-Myers Squibb, Eli Lilly, Genentech/Roche GSK, Janssen, and UCB, Atul Singhal Consultant of: AbbVie, Aclaris, Amgen, AstraZeneca, Bristol-Myers Squibb, Eli Lilly, Gilead, Idorsia, Novartis, Oscotec 
Pfizer, Regeneron, Roche/Genentech, Sanofi, Selecta, Takeda, UCB, and Viela Bio, Grant/research support from: AbbVie, Aclaris, Amgen, AstraZeneca, Bristol-Myers Squibb, Eli Lilly, Gilead, Idorsia, Novartis, Oscotec, Pfizer, Regeneron, Roche/Genentech, Sanofi, Selecta, Takeda, UCB, and Viela Bio, Jerzy Swierkot Speakers bureau: AbbVie, Accord, BMS, Janssen, MSD, Pfizer, Roche, Sandoz, and UCB, Consultant of: AbbVie, Accord, BMS, Janssen, MSD, Pfizer, Roche, Sandoz, and UCB, Grant/research support from: AbbVie, Accord, BMS, Janssen, MSD, Pfizer, Roche, Sandoz, and UCB, Alan Friedman Shareholder of: May own stock or options in AbbVie, Employee of: AbbVie, Nasser Khan Shareholder of: May own stocks or options in AbbVie, Employee of: AbbVie, Yihan Li Shareholder of: May own stocks or options in AbbVie, Employee of: AbbVie, Xianwei Bu Shareholder of: May own stocks or options in AbbVie, Employee of: AbbVie, Justin Klaff Shareholder of: May own stock or options in AbbVie, Employee of: AbbVie, Vibeke Strand Consultant of: AbbVie, Amgen, Arena, AstraZeneca, Bayer, Bristol-Myers Squibb, Boehringer Ingelheim, Celltrion, Eli Lilly, Genentech/ Roche, Gilead, GSK, Ichnos, Inmedix, Janssen, Kiniksa, MSD, Myriad Genetics, Novartis, Pfizer, Regeneron, Sandoz, Sanofi, Setpoint, and UCB DOI: 10.1136/annrheumdis-2021-eular.530

\section{POS0656 RELATIONSHIP BETWEEN CHANGES IN LIPID LEVELS AND IMPROVEMENT IN DISEASE ACTIVITY OUTCOMES IN PATIENTS WITH RHEUMATOID ARTHRITIS RECEIVING UPADACITINIB TREATMENT: POOLED ANALYSIS OF DATA FROM TWO PHASE 3 STUDIES}

C. Charles-Schoeman ${ }^{1}$, J. T. Giles ${ }^{2}$, N. Lane ${ }^{3}$, E. Choy ${ }^{4}$, H. Camp ${ }^{5}$, Y. Song ${ }^{5}$, S. Anyanwu ${ }^{5}$, I. Mclnnes ${ }^{6}{ }^{1}$ University of California, Rheumatology, Los Angeles, United States of America; ${ }^{2}$ Columbia University, Rheumatology, New York, United States of America; ${ }^{3}$ University of California, Davis, Sacramento, United States of America; ${ }^{4}$ Cardiff University, School of Medicine, Cardiff, United Kingdom; ${ }^{5} \mathrm{AbbVie}$ Inc., Rheumatology, North Chicago, United States of America; ${ }^{6}$ University of Glasgow, Rheumatology, Glasgow, United Kingdom

Background: Upadacitinib (UPA) is an oral Janus kinase (JAK) inhibitor engineered to have greater selectivity for JAK1 vs JAK2, JAK3, and tyrosine kinase 2 , and is approved for the treatment of RA. Across 2 double-blind, placebo (PBO)-controlled Phase 3 studies of UPA in patients with RA, after an initial increase through Week 8 , lipid levels remained stable up to Week 24. ${ }^{1,2}$ Previous studies of JAK or IL-6 receptor inhibitors have reported a negative correlation between changes in lipid levels and RA disease activity. ${ }^{3,4}$

Objectives: To determine the relationship between changes in lipid levels and disease activity outcomes in patients with RA treated with UPA.

Methods: Patients with RA and an inadequate response to conventional synthetic/biologic DMARDs (cs/bDMARD-IR) from SELECT-NEXT/SELECT-BEYOND, respectively, were randomized to receive UPA $15 \mathrm{mg}$ once daily (QD), UPA $30 \mathrm{mg}$ QD, or PBO for 12 weeks followed by an extension of up to 5 years; patients randomized to PBO switched to UPA 15 or $30 \mathrm{mg}$ after 12 weeks. Spearman correlations of maximum changes from baseline (BL) through Week 12 in fasting-state lipid levels (low- and high-density lipoprotein cholesterol [LDL-C; $\mathrm{HDL}-\mathrm{C}]$, and total cholesterol [TC]) with clinical disease activity outcomes measured by change from BL in Clinical Disease Activity Index (CDAI), DAS of 28 joints using CRP (DAS28[CRP]), tender/swollen joint count in 28 joints (TJC28/ SJC28), and pain by visual analog scale (VAS) at Weeks 12 and 24, were determined. Spearman correlations of maximum changes from $\mathrm{BL}$ in lipid levels and CRP through Week 12 were also determined.

Results: Available fasting samples from 1,160 pooled patients (UPA $15 \mathrm{mg}$, $\mathrm{n}=386$; UPA $30 \mathrm{mg}, \mathrm{n}=384 ;$ PBO, $\mathrm{n}=390$ ) were included. Modest, but statistically significant, negative correlations were observed between maximum changes from $\mathrm{BL}$ in TC through Week 12 and change from BL in CDAl, DAS28(CRP), SJC28, and pain (VAS) at Week 12 with UPA 15 or $30 \mathrm{mg}$ (Figure 1); similar trends were observed at Week 24. Significant correlations between changes in LDL-C and HDL-C and disease activity outcomes were also observed, but were not consistent across UPA doses and time points. No significant correlations were noted between changes in lipid levels and disease activity outcomes in the PBO group. Statistically significant weak negative relationships were observed between maximum changes from $B L$ in lipid levels and CRP levels through Week 12 with UPA $15 \mathrm{mg}$ (HDL-C and TC) or UPA $30 \mathrm{mg}$ (LDL-C and TC) (Table 1).

Conclusion: In this large pooled data set of patients receiving UPA, increases in lipid levels showed modest, but statistically significant, correlations with improvement in clinical disease activity outcomes in patients with cs/bDMARD-IR RA. These results add to evidence suggesting a relationship between systemic inflammation and lipid metabolism in patients with RA, which is modifiable with effective interventions, and reinforce the importance of monitoring for hyperlipidemia in these patients.

REFERENCES:

[1] Burmester GR, et al. Lancet 2018;391:2503-12.

[2] Genovese MC, et al. Lancet 2018;391:2513-24.
[3] Kremer JM, et al. Arthritis Rheumatol 2017;69:943-52.

[4] Cacciapaglia F, et al. Mediators Inflamm 2018;2018:2453265.

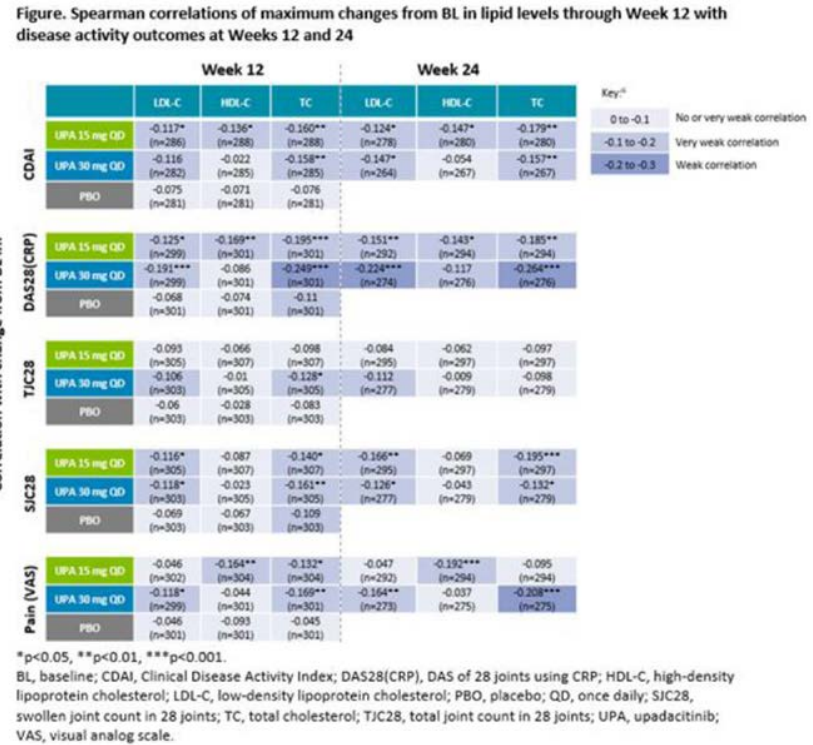

Table 1. Spearman correlation of maximum changes from BL in lipid levels through Week 12 with maximum change from BL in CRP through Week 12

\begin{tabular}{lccc}
\hline & UPA $15 \mathrm{mg}$ QD & UPA 30 mg QD & PBO \\
\hline LDL-C & $-0.099(n=303)$ & $-0.174^{\star *}(n=302)$ & $-0.053(n=303)$ \\
HDL-C & $-0.184^{\star \star}(n=305)$ & $-0.087(n=304)$ & $-0.024(n=303)$ \\
TC & $-0.189^{\star * *}(n=305)$ & $-0.236^{\star \star *}(n=304)$ & $-0.056(n=303)$ \\
\hline
\end{tabular}

${ }^{\star *} \mathrm{p}<0.01,{ }^{\star \star \star} \mathrm{p}<0.001$

HDL-C, high-density lipoprotein cholesterol; LDL-C, low-density lipoproteincholesterol; PBO, placebo; QD, once daily; TC, total cholesterol; UPA, upadacitinib

Acknowledgements: AbbVie funded this study and participated in the study design, research, analysis, data collection, interpretation of data, reviewing, and approval of the publication. All authors had access to relevant data and participated in the drafting, review, and approval of this publication. No honoraria or payments were made for authorship. Medical writing assistance was provided by Frances Smith, PhD, of 2 the Nth, which was funded by AbbVie.

Disclosure of Interests: Christina Charles-Schoeman Consultant of: AbbVie, Gilead, Pfizer, and Regeneron-Sanofi., Grant/research support from: AbbVie, Bristol-Myers Squibb, and Pfizer, Jon T Giles Consultant of: AbbVie, Bristol-Myers Squibb, Eli Lilly, and Gilead, Grant/research support from: Pfizer, Nancy Lane Speakers bureau: Amgen and Mallinckrodt, Consultant of: Amgen, Mallinckrodt, Pfizer, and Roche, Ernest Choy Speakers bureau: AbbVie, Amgen, AstraZeneca, Bio-Cancer, Biogen, Bristol-Myers Squibb Boehringer Ingelheim, Celgene, Chugai Pharma, Eli Lilly, Ferring Pharmaceuticals, GlaxoSmithKline, Hospira, Janssen, Merck Sharp \& Dohme, Napp Novimmune, Novartis, ObsEva, Pfizer, Regeneron, Roche, R-Pharm, Sanofi, SynAct Pharma, Synovate, Tonix, and UCB, Grant/research support from: AbbVie, Amgen, AstraZeneca, Bio-Cancer, Biogen, Bristol-Myers Squibb Boehringer Ingelheim, Celgene, Chugai Pharma, Eli Lilly, Ferring Pharmaceuticals, GlaxoSmithKline, Hospira, Janssen, Merck Sharp \& Dohme, Napp Novimmune, Novartis, ObsEva, Pfizer, Regeneron, Roche, R-Pharm, Sanofi SynAct Pharma, Synovate, Tonix, and UCB, Heidi Camp Shareholder of: AbbVie, Employee of: AbbVie, Yanna Song Shareholder of: AbbVie, Employee of: AbbVie, Samuel Anyanwu Shareholder of: AbbVie, Employee of: AbbVie Iain Mclnnes Consultant of: AbbVie, Celgene, Janssen, Novartis, and UCB Grant/research support from: Celgene, Janssen, Novartis, Pfizer Inc., Roche, and UCB

DOI: 10.1136/annrheumdis-2021-eular.606

\section{POS0657 GEOGRAPHIC VARIATION OF SAFETY IN THE FILGOTINIB RHEUMATOID ARTHRITIS PROGRAM}

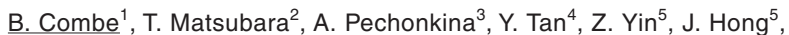
R. Besuyen ${ }^{6}$, A. Gomez-Centeno ${ }^{7}$, M. H. Buch ${ }^{8} .{ }^{1}$ University of Montpellier, Department of Rheumatology, Montpellier, France; ${ }^{2}$ Matsubara Mayflower Hospital, Department of Orthopaedic Surgery, Kato, Japan; ${ }^{3}$ Gilead 